\author{
International Journal of Entrepreneurship and \\ Management Practices (IJEMP) \\ Journal Website: http://ijemp.com/ \\ eISSN: $2600-8750$
}

\title{
EFFECT OF ENVIRONMENTAL UNCERTAINTIES ON THE RELATIOSHIP OF ENTREPRENEURIAL ORIENTATION AND BUSINESS SUCCESS: CHILD CARE CENTRES IN MALAYSIA
}

\author{
Tan Hong Hooi ${ }^{1}$ \\ 1 Faculty of Business, KDU Penang University College, Penang, Malaysia. \\ Email: hoonghooi.tan@kdupg.edu.my
}

\section{Article Info:}

\section{Article history:}

Received date:23.12.2019

Revised date: 28.01 .2020

Accepted date: 04.05.2020

Published date: 15.06.2020

\section{To cite this document:}

Tan, H. H. (2020). Effect of Environmental Uncertainties on The Relationship of Entrepreneurial Orientation and Business Success: Child Care Centres in Malaysia. International Journal of Entrepreneurship and Management Practices, 3 (10), 30-42.

DOI: 10.35631/IJEMP.310003.

\begin{abstract}
:
The main objective of this study is to examine the moderating role of environmental uncertainties on the relationships between entrepreneurial orientation (EO) being innovativeness, risk-taking, and pro-activeness and performance of childcare centres in Malaysia. Data were collected from the childcare centres operating in the whole of Malaysia using a quantitative survey design. The study adopted a cluster sampling, respondents were selected from the population of 3,490 childcare centres in Malaysia, and questionnaires were distributed through the postal method and online survey method. A total of 117 usable questionnaires were returned, giving a response rate of 29.7\%. Partial Least Squares-Structural Equation Modeling (PLSSEM) was used to test the study hypotheses. The findings revealed that Entrepreneurial orientations are important strategic orientations for the performance of childcare centres in Malaysia. The findings of the study supported the hypothesized positive relationship between innovativeness and pro-activeness to business success but no relationship between risk-taking and business success. For the moderating effect, perceived environmental uncertainties were found to have a moderating effect on innovativeness but not to risk-taking and pro-activeness. The findings of this study provide important insights to owners/managers of childcare centres in Malaysia, policymakers, and researchers to further understand the effects of EO on the performance of childcare centres in Malaysia. Owners in the childcare centres in Malaysia should also be encouraged to improve their entrepreneur orientation which may increase their performances. Finally, the study implications, limitations as well suggestions for future research are discussed.
\end{abstract}

\section{Keywords:}

Entrepreneurial Orientation, Environmental Uncertainties, Child Care Centres 


\section{Introduction}

Research indicates that small businesses tend to have a higher failure rate as compared to large organisations, although they are commonly perceived as an engine of a country's economy (Bloch \& Bhattacharya, 2016; Lo et al., 2016). In Malaysia, performance of SMEs deteriorated in first quarter of 2017 as compared to the first quarter of 2016(SME Corp, 2017). Studies by Abdullah et al. (2009) showed that $13 \%$ of entrepreneurs decided to close down their business after 5 years of their organizational inception in 2005 in Malaysia despite Malaysia is a developing country. The expected failure rate of small and medium enterprises (SMEs) in Malaysia is about 60\% (Khalique, 2015).

Survival and performance of SMEs in Malaysia is an issue of great concern, as the failure rate is high and increasing, there is also negative impact on Malaysia's GDP. This has motivated us to do an empirical investigation on Malaysia SMEs performance in this regard. Although performance of the business has been the dependent variable in the past researcher (Rauch et al., 2009; Wales et al., 2015; Martens et al., 2016), however, business performance of childcare centre in Malaysia was still very lack.

As Malaysia is moving in the direction to become a developed country in 2020, family income is increasing too, early childhood education is given more emphasis which has caused the enrolment in the childcare centres to increase. Therefore, it also gives rise to the increase in number of the childcare centres. In 2016, approximately 853 childcare centres have registered with the Social Welfare Department. Due to the increase maternal participation in labour force in Malaysia, the demand for childcare has increased. The demand increase is even faster in developing nations like Malaysia, Hong Kong and Singapore. Furthermore, woman education level in those countries have also improved as compared to previously which lead to more women holding senior positions in business, government and education field (Bhosale \& Gupta, 2006). According to Malaysia Labour Survey, 2015, female participation rate in the labour force has increased by $0.4 \%$ to $54.1 \%$ in 2015 . The age group that has highest participation rate in the workforce is between the age of 25-54 years which was $58 \%$ of the total workforce. Besides that, as Malaysian parents now become more and more wealthy, they can afford to pay for the education for their children, hence it led to the increase demand in childcare services (Tee \& Richardson, 2007).

\section{Objective}

The objective of our research is to identify the business success factors among childcare centre in Malaysia by focusing on EO and business success. The second research aim is to investigate the moderating effect of environmental uncertainties between entrepreneurial orientation and business success. The result of the studies is to raises a further need for organizations to apply an empirical EO model to be more proactively in improving their services to the customers. This includes not only to address the customers' needs, but also to create value to the customers as well.

\section{Research Questions}

i. Is there significant relationship between entrepreneurial orientation (which comprises of innovativeness, risk-taking and pro-activeness to perceived business success of childcare centres in Malaysia?

ii. Does perceived environmental uncertainties moderate the relationship between entrepreneurial orientation and perceived business success of childcare centres in Malaysia? 


\section{Research Gap}

Theoretically, there were extensive literatures investigating the factors contribute to business success. There was also extensive literature conducted to investigate the link between entrepreneur orientation and business performance (Herath \& Mahmood, 2014; Wiklund \& Shepherd, 2011) but those researches produced confusing results. Therefore, there is still theoretical gap which could be addressed in this study.

Some of the literature reports inconclusive findings regarding entrepreneurial orientation and business performance relationship, which calls for more empirical attention in this area. There were some studies which found some direct and indirect relationship between entrepreneurial orientation and business performance (Schepers et al., 2014; Van Doorn et al., 2013; Vij \& Bedi, 2012).On the other hand, there are also studies which found no significant relationship between the entrepreneurial orientation and business performance (Fuentes et al., 2015;Dai, 2014; Kreiser et al., 2013; Tang \& Tan, 2012; Baker \& Sinkula, 2009; Stam \& Elfring, 2008).

\section{Research Model and Hypothesis Testing}

Entrepreneurial orientation is the independent variable which consists of three dimensions: innovativeness, pro-activeness, and risk taking. The dependent variable is perceived business performance which consists of financial and non-financial performance. The present study conceptualised that influence of entrepreneurial orientation dimensions toward business performance depending on the value of environmental uncertainty. In other words, environmental uncertainty moderates the relationship between entrepreneurial orientation and business performance.

\section{Research Methodology}

The present study employs an explanatory type of study as it attempts to identify the relationships between entrepreneurial orientation and business success of the child care centre. The data collection method is survey using questionnaire with closed-ended questions. The study adopted a cluster sampling, respondents were selected from the population of 3,490 childcare centres in Malaysia, and questionnaires were distributed through the postal method and online survey method. A total of 117 usable questionnaires were returned, giving a response rate of $29.7 \%$. This correspond with the estimated response rate of questionnaire in Malaysia of $25 \%$.

Operationalisation of Measurement of Variables

\begin{tabular}{|c|c|c|c|}
\hline VARIABLE & $\begin{array}{l}\text { OPERATIONAL } \\
\text { DEFINITION/ }\end{array}$ & $\begin{array}{l}\text { RELIABILITY } \\
\text { FROM } \\
\text { ADAPTED } \\
\text { SOURCE } \\
\end{array}$ & $\begin{array}{l}\text { SOURCE } \\
\text { OFADOPTION }\end{array}$ \\
\hline Business success & $\begin{array}{l}\text { This is defined as } \\
\text { the perception of } \\
\text { the owner about } \\
\text { business growth } \\
\text { and efficiency. }\end{array}$ & $\begin{array}{l}\text { Cronbach's } \\
\text { Alpha Result } \\
\text { from adapted } \\
\text { source }=0.85\end{array}$ & $\begin{array}{l}\text { Govindarajan } \\
\text { (1988). }\end{array}$ \\
\hline Innovativeness & $\begin{array}{l}\text { This is defined as } \\
\text { the ability of the } \\
\text { centre to innovate }\end{array}$ & $\begin{array}{lr}\text { Cronbach } & \text { 's } \\
\text { Alpha } & \text { Result } \\
\text { from } & \text { adapted }\end{array}$ & $\begin{array}{l}\text { Covin \& Slevin } \\
\text { (1989), } \\
\text { Lumpkin \& }\end{array}$ \\
\hline
\end{tabular}




\begin{tabular}{|c|c|c|c|}
\hline & $\begin{array}{l}\text { and continuously } \\
\text { improve }\end{array}$ & source $=0.87$ & Dess (1996). \\
\hline Risk-taking & $\begin{array}{l}\text { This is defined as } \\
\text { the ability to take } \\
\text { risk and to exploit } \\
\text { opportunities }\end{array}$ & $\begin{array}{l}\text { Cronbach 's } \\
\text { Alpha Result } \\
\text { from adapted } \\
\text { source }=0.71\end{array}$ & $\begin{array}{l}\text { Covin \& Slevin } \\
(1989), \\
\text { Lumpkin \& } \\
\text { Dess (1996). }\end{array}$ \\
\hline Pro-activeness & $\begin{array}{l}\text { This is defined as } \\
\text { being aggressive } \\
\text { and respond to } \\
\text { competitions }\end{array}$ & $\begin{array}{l}\text { Cronbach 's } \\
\text { Alpha Result } \\
\text { from adapted } \\
\text { source }=0.8\end{array}$ & $\begin{array}{l}\text { Covin \& Slevin } \\
(1989), \\
\text { Lumpkin \& } \\
\text { Dess (1996). }\end{array}$ \\
\hline
\end{tabular}

\section{Literature Review}

Numerous research had also been done to investigate the relationship between entrepreneurial orientation and business performance (De Clercq et al., 2013; Filser\& Eggers, 2014; Schepers et al., 2014; Shehu and Mahmood, 2014) Most of the findings were mixed. Some researchers argued that a high level of EO leads to superior performance (AlNuiami et al., 2014; Hughes et al., 2012; Madsen, 2007; Schepers et al., 2014; Van Doorn et al., 2013; Vij and Bedi, 2012; Wiklund, 1999) as well as positive effect on business growth (Alarape, 2013; Laukkanen et al., 2013; Moreno \& Casillas, 2008; Soininen et al., 2012). Wales (2016) also explained that there is a positive relationship between $\mathrm{EO}$ and firm performance.

However, Slater and Narver, (2000), Stam and Elfring (2008), Baker and Sinkula (2009) found mismatch between EO and performance in organization. In some other studies, EO is found to have a U-shaped relationship with firm performance (Tang et al., 2008; Tang \& Tan, 2012; Kreiser et al. 2013; Su et al., 2015).

According to them, one possible reason for the variation is the existence of other variables that moderate the relationship between EO and business success. Li \& Tang (2010) believed that there are third variables that moderate EO and performance of the firm. Although scholars are interested in finding out what are the possible variables that moderate the relationship between entrepreneurial orientation on business success, limited studies have been done in this aspect (Huang \& Wang, 2011).

Most of the studies only investigated direct relationship between EO and business success. However, there were very limited studies that reported on the moderating factor of EO and business success (Frese et al., 2002; Wiklund \& Shepherd, 2003). Although the moderator between EO and business success were also discussed by Covin and Slevin, 1991; Lumpkin and Dess (2001); Yusuf (2002); Kraus et al. (2012); Boso et al. (2013); Wales et al. (2013); Su et al. (2015), however, there is little consensus about which are the suitable moderators to the relationship. Hence, the moderating effect of EO and firm performance will contribute to greater understanding of the relationship between entrepreneurial orientation and business success. 
Business success in this study is measured by the childcare centre's owner perception toward business success. This is measured by to what extent they are satisfied with the financial and non-financial performance of their centres as compared to their competitors in terms of sales level, sales growth rate, effectiveness, better competitive position and employees' job satisfaction. In this study, respondents were asked to indicate their perception of success criteria ranging from "strongly agree" to "strongly disagree"

Entrepreneurial orientation is believed to be one of the important factors in determining the success, development and sustainability of a business (Lechner \& Gudmundsson, 2014; Lindsay et al., 2014; Shehu \& Mahmood, 2014). It is believed that entrepreneurial orientation can lead to better business performance (Rauch et al., 2009; Wales et al., 2013; Gupta \& Dutta, 2016).

Prajogo (2015) pointed out the importance of innovation in the entrepreneurial process. According to him, 'creative destruction' is disruptive innovation, this is because new products, services or processes have been created and they disrupt the current trend in the market and customers' taste. Innovativeness is also seen as developing or applying creative ideas or solutions to the challenges existing in the competitive business environment today (Clausen \& Korneliussen, 2012; Covin \& Miller, 2014). According to Lumpkin \& Dess (1996), a business which is innovative will tend to engage in creating new ideas or new processes, this will enable the business to produce new products, services or technology.

According to Hughes and Morgan, (2007), Kraus et al., (2012), Wang and Yen (2012), DeClercqet al. (2013), Fern et al. (2012), risk is linked with an organization's willingness to make bold and daring resource commitments toward organizational initiatives with uncertain returns (Wales et al., 2013). Hence, risk-taking is described as facing uncertainty in the environment and behave entrepreneurially.

Pro-activeness means forward looking other than being innovative in new venturing activity (Covin \& Lumpkin, 2011; Semrau et al., 2016; Linton \& Kask, 2017). This is an important dimension of entrepreneurial orientation. In the early formulation of pro-activeness, Miller and Friesen (1978) defined pro-activeness as to what extent a firm is shaping the environment through introduction of new products, new technologies or administrative techniques. The firms which score high in pro-activeness shape the environment rather than react to the environment. They also refer pro-activeness as a process which aimed at anticipating and acting on future needs by seeking new opportunities which may or may not be related to the present line of operations, introduction of new products and brands ahead of competition, strategically eliminating operations which are in the mature or declining stages of life cycle (Miller \& Friesen, 1989). 


\section{Findings}

\section{Research Finding}

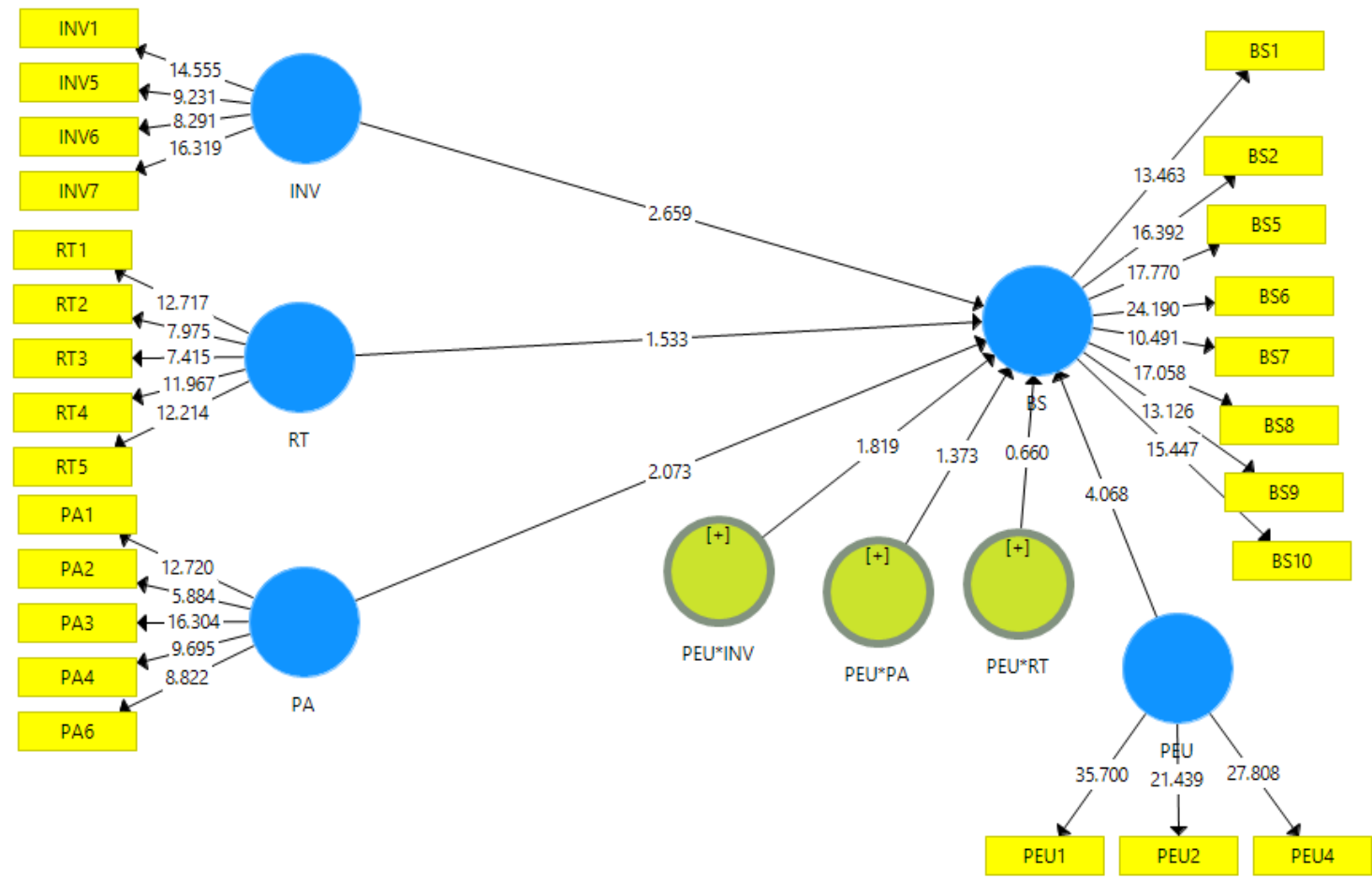

PLS-Path analysis of $t$-values $(n=117)$

\begin{tabular}{lllllllll}
\hline & & Beta & $\begin{array}{l}\text { Std } \\
\text { Error }\end{array}$ & $\begin{array}{l}\text { T } \\
\text { Value }\end{array}$ & $\begin{array}{l}\text { P } \\
\text { Values }\end{array}$ & $\mathbf{5 . 0 0 \%}$ & $\mathbf{9 5 . 0 0 \%}$ & reason \\
\hline $\begin{array}{l}\text { Innovativeness } \\
\text { Business success }\end{array}$ & $->$ & 0.363 & 0.146 & 2.480 & 0.007 & 0.098 & 0.573 & supported \\
$\begin{array}{l}\text { Pro-activeness } \\
\text { Business success } \\
\begin{array}{l}\text { Risk-taking } \\
\text { Business success }\end{array}\end{array}$ & $->$ & 0.298 & 0.146 & 2.040 & 0.021 & 0.062 & 0.542 & supported \\
\hline
\end{tabular}

\begin{tabular}{|c|c|c|c|c|c|c|c|c|}
\hline & & Beta & $\begin{array}{r}\text { Std } \\
\text { Error }\end{array}$ & $\begin{array}{r}T \\
\text { Values }\end{array}$ & $\begin{array}{r}\mathbf{P} \\
\text { Values }\end{array}$ & $5.00 \%$ & $95.00 \%$ & reason \\
\hline $\begin{array}{l}\text { INV*PEU } \\
\text { Business } \\
\text { success }\end{array}$ & $->$ & -0.022 & 0.145 & 0.151 & 0.44 & -0.248 & 0.219 & $\begin{array}{l}\text { Not } \\
\text { supported }\end{array}$ \\
\hline $\begin{array}{l}\text { PA*PEU } \\
\text { Business } \\
\text { success }\end{array}$ & $->$ & -0.233 & 0.139 & 1.684 & 0.046 & -0.476 & -0.044 & $\begin{array}{l}\text { Not } \\
\text { supported }\end{array}$ \\
\hline $\begin{array}{l}\text { RT*PEU } \\
\text { Business } \\
\text { success }\end{array}$ & $->$ & 0.213 & 0.123 & 1.73 & 0.042 & 0.017 & 0.389 & supported \\
\hline
\end{tabular}


The hypothesis can be summarised as below:

$\mathrm{H} 1$ : Innovativeness is positively related to business success of childcare centres is supported with $\beta=0.254, \mathrm{t}=2.659, \mathrm{p}<0.01$.

$\mathrm{H} 2$ : Risk-taking is positively related to business success of childcare centre is not supported with $\beta=0.135, \mathrm{t}=1.533, \mathrm{p}<0.01$.

H3: Pro-activeness is positively related to business success of childcare centre is supported with $\beta=0.246, \mathrm{t}=2.037, \mathrm{p}<0.01$.

H4: Perceived environmental uncertainties positively moderate the relationship between innovativeness and business success of the childcare centre is supported with $\beta=0.193, \mathrm{t}=$ $1.819, \mathrm{p}<0.01$.

H5: Perceived environmental uncertainties positively moderate the relationship between risktaking and business success of the childcare centre is not supported with $\beta=0.092, t=0.660$, $\mathrm{p}<0.01$.

H6: Perceived environmental uncertainties positively moderate the relationship between proactiveness and business success of the childcare centre is not supported with $\beta=-0.214, t=$ $1.373, \mathrm{p}<0.01$

The PLS path Modeling results suggested that innovativeness has significant relationship with business success. Pro-activeness also has significant relationship with business success. However, risk-taking was not found to have significant relationship with business success. As for moderating effect of perceived environmental uncertainties on innovativeness, the findings support perceived environmental uncertainties moderate the relationship between risk taking and business success. On the contrary, perceived environmental uncertainties were not found to moderate pro-activeness and innovations on business success relationship.

\section{Research Implication}

The significant positive relationship shows that as innovativeness increases business success of childcare centre in Malaysia will also increase. On the other hand, this shows that a higher level of innovativeness would result in a higher level of business success of childcare centre in Malaysia and vice-versa.

There is no significant relationship between risk-taking and business success in childcare centre. The relationship does not indicate that as risk-taking increase business success of childcare centre in Malaysia will increases. This is because entrepreneurs of the childcare centre consider taking risk is not suitable in the childcare industry. Childcare centre is operating in a more conservative environmental as compared to other manufacturing, service or industrial environment where risk taking is one of the most important dimensions in the entrepreneurial orientation construct. In education industry where childcare centre is operating in, taking risky actions are not conducive and finally do not contribute to business success. The entrepreneurs in the childcare centre think that taking additional risk will not be good for their business, they will rather be more conservative, this can be due to the nature of the industry where it is based

The significant positive relationship shows that as pro-activeness increases business success of childcare centre in Malaysia will also increase. On the other hand, this shows that a higher level of pro-activeness would result in a higher level of business success of childcare centre in Malaysia and vice-versa.

The results from this study has confirmed and acknowledged the importance of entrepreneurial orientation for the business success of childcare centres in Malaysia. We live 
in a world that is very fast paced, there are a lot of changes in the business, with the intensity of technology and globalization, business and product life cycles are getting shorter. Due to the changes of technology, a lot of products are experiencing continuous improvements and the current business environment has become very dynamic, competitive and complex. Therefore, the entrepreneurs of childcare centres should increase their level of entrepreneurial orientation in order to survive in the ever changing and competitive business environment.

The result found that perceived environmental uncertainties moderate the relationship between innovativeness and business success of childcare centre in Malaysia.

Perceived environmental uncertainties have moderating effect between innovativeness and business success of childcare centre in Malaysia because perceived environmental uncertainties can act as opportunities well as threats to the childcare centre (Kuratko \& Hodgetts, 2004).

In order to survive in a competitive business environment, the centre needs to consistently monitor and screen their internal and external environment to identify whether there are any challenges or opportunities exist. Constant evaluation of the environment will help the owners or the entrepreneurs of the firms to understand different factors that may affect their firms and understand the effects of these different factors on their firms. Therefore, under uncertain environment, the owner of the childcare centre has to be innovativeness enough to respond to the changes in the environment (Ramlall, 2002).

The result of moderation test for perceived environmental uncertainties on the relationship between risk-taking and business success of childcare centre in Malaysia indicated that perceived environmental uncertainties does not moderate the relationship between risk-taking and business success of childcare centre in Malaysia.

The result of moderation test for perceived environmental uncertainties on the relationship between pro-activeness and business success of childcare centre in Malaysia indicated that perceived environmental uncertainties does not moderate the relationship between proactiveness and business success of childcare centre in Malaysia.

From a practical business point of view, it can be argued that it is important to understand the relationship between entrepreneurial orientation and business success of childcare centre. The childcare centre is to provide service to others. In order to sustain its competitive advantage, they have to differentiate from its competitors in terms of the services provided.

\section{References}

Abdullah, F., Hamali, J., Deen, A.R., Saban, G. \& Abdurahman, A. Z. (2009). Developing A Framework of Success of Bumiputera Entrepreneurs. Journal of Enterprising Communities: People and Places in the Global Economy. 3(1), 8-24.

Al-Nuiami, M., Subhi Idris, W.M., Moh'd Al-Ferokh, F.A., Moh'd Abu \& Joma, Md.H. (2014). An empirical study of the moderator effect to entrepreneurial orientation on the relationship between environmental turbulence and innovation performance in five-star hotels in Jordan. International Journal of Business Administration. 5(2), 111125.

Aragón-Correa, J. A. \& Rubio-López, E.A. (2007). Proactive corporate environmental strategies: Myths and misunderstandings. Long Range Planning, 40(3), 357-381. 
Awang, A. (2009). Entrepreneurial Orientation and Performance Relations of Malaysian Bumiputera SMEs: The Impact of Some Perceived Environmental Factors. International Journal of Business and Management, 9 (9).

Aziz, N. N. \& Samad, S (2016). Influence of organizational capability on competitive advantage in small and medium enterprises (SMEs). International Business Management, 10(18), 4163-4171.

Baker, W.E. \& Sinkula, J.M. (2009). Learning orientation, market orientation, and innovation: integrating and extending models of organizational performance. Journal of market focused management, 4(4), 295-308.

Baker, M., Gruber, J. and Milligan, K. (2015). Non-cognitive deficits and young adult outcomes: The long-run impacts of a universal childcare program. Working Paper 21571, National Bureau of Economic Research.

Barshay, J. (2015). Studies shed light on fleeting benefits of early childhood education. U.S. News \& World Report News. The Hechinger Report.

Barney, J. (2001). Is the resource-based "view" a useful perspective for strategic management research? Yes". Academy of Management Review, 26 (1), 41-56.

Batjargal, B. (2007). Network triads: Transitivity, referral and venture capital decisions in China. Journal of International Business Studies, 38: 998-1012.

Bhosale \& Gupta (2006). Relationship between entrepreneurial orientation and firm performance in large organizations over time. Journal of International Entrepreneurship, 13(1),7-27.

Bitler, M. P., Hoynes, H. W. \& Domina, T. (2014). Experimental evidence on distributional effects of Head Start. Working Paper 20434, National Bureau of Economic Research.

Burt, R. S. \& Burzynska, K. (2017). Chinese entrepreneurs, social networks, and guanxi. Management and Organization Review, 13(2).

Campbell, F. A., Conti, G., Heckman, J. J., Moon, S. H., Pinto, R. \& Pungello, E. P. (2014). Early childhood investments substantially boost adult health. Science, 343 (6178), $1478-1485$.

Children Statistic Malaysia (2017). Department Of Statistics Malaysia, Press Release Children Statistics, Malaysia. https://www.dosm.gov.my/v1/index.php?r=column/pdfPrev\&id=WGlmVnppZ2J6b2h GZHFQMmxWQ2UwUT09

Chris M. H. \& Erdal, T. (2010). Childcare subsidies and child development, Economics of Education Review, 26, 52-66.

Collis, M. \& Montgomery, M. (1995). First-mover advantages. Strategic Management Journal, 9: 41-58.

Covin, J. G. \& Slevin, D.P. (1989). Strategic management of small firms in hostile and benign environments. Strategic Management Journal, 10(1), 75-87.

Covin, J. G. \& Lumpkin, G. T. (2011). Entrepreneurial Orientation Theory and Research: Reflections on a Needed Construct. Entrepreneurship Theory and Practice, 855-872.

Covin, G. J. \& Miller, D. (2014). International entrepreneurial orientation: conceptual considerations, research themes, measurement issues, and future research directions. Entrepreneurship: Theory \& Practice, 38 (1), 11-44.

Cunha, F. (2015). Subjective rationality, parenting styles, and investments in children. In P. R. Amato, A. Booth, S. M. McHale, and J. Van Hook (Eds.), Families in an Era of Increasing Inequality: Diverging Destinies, National Symposium on Family Issues Series, 6, 83-94. New York: Springer.

Dai L, Maksimov V, Gilbert B \& Fernhaber S. (2014). Entrepreneurial orientation and international scope: The differential roles of innovativeness, pro-activeness, and risktaking. Journal of Business Venturing, 29(4): 511-524. 
Department of statistics Malaysia press release (2017). Retrieved 15 May 2017, from https://www.dosm.gov.my/v1/index.php?r=column/pdfPrev\&id=eDg2N01TWG xTd3JzTlpwMXFUejRydz09.

Duncan, R. B. (1972). Characteristic of organizational environments and perceived environmental uncertainty. Administrative Science Quarterly 17: 313-327

Edmond, V. \& Wiklund, J. (2010). The historic roots of entrepreneurial orientation research, in.

Foss, N.J., Lyngsie, J. \& Zahra, S.A. (2013). The role of external knowledge sources and organizational design in the process of opportunity exploitation. Strategic Management Journal, 34 (12), 1453-1471.

Fritsch, M. \& Storey, D. J. (2017), Entrepreneurship in a Regional Context, Routledge, 11.

Fuentes-Fuentes M, Bojica A \& Ruiz-Arroyo, M. (2015). Entrepreneurial orientation and knowledge acquisition: effects on performance in the specific context of womenowned firms. International Entrepreneurship and Management Journal, 695-717.

Gimenez, C. \& Ventura, E. (2002). Supply Chain Management as a competitive advantage in the Spanish grocery sector. Working paper No. 641, Universitat Pompeu Fabra. Forthcoming in the International Journal of Logistics Management.

Govindarajan, V. (1988). A contingency approach to strategy implementation at the businessunit level: integrating administrative mechanisms with strategy. Academy of Management Journal, 31(4), 828-853.

Gnizy, I., Baker, W.E. \& Grinstein, A. (2014). Proactive learning culture: A dynamic capability and key success factor for SMEs entering foreign markets. International Marketing Review, 31(5), 477-505.

Guzmán, G.M., Gutiérrez, J.S., Cortes, J.G. \& Ramírez, R.G. (2012). Measuring the competitiveness level in furniture SMEs of Spain. International Journal of Economics and Management Sciences, 1(11), 9-19.

Havnes, T. and Mogstad, M. (2014). Is universal childcare levelling the playing field? Journal of Public Economics, 127, 100-114

Herath, H.M. and Mahmood, R. (2014). Strategic orientations and SME performance: moderating effect of absorptive capacity of the firm. Asian Social Science, 10(13), 95107.

Hughes, M. \& Morgan, R. E. (2009). Deconstructing the relationship between entrepreneurial orientation and business performance at the embryonic stage of firm growth. Industrial Marketing Management, 36(5), 651-661.

Iram, U. \& Butt, M. S. (2004). Socioeconomic and environmental determinants of child-care patterns of preschoolers in Pakistan. International Journal of Social Economics, vol. 31(3), 218-238.

Jangga, R., Ali, N. M., Ismail, M. \& Sahari, N. (2015). Effect of environmental uncertainty and supply chain flexibility towards supply chain innovation: an exploratory study. Procedia Economics and Finance, 31, 262-268.

Javalgi, R. R. \& Todd, P.R. (2011). Entrepreneurial orientation, management commitment, and human capital: The internationalization of SMEs in India. Journal of Business Research, 64(9), 1004-1010.

Khalique, M., Bontis, N., Shaari, J.A.N., \& Md. Isa, A.H. (2015). Intellectual capital in small and medium enterprises in Pakistan. Journal of Intellectual Capital, 16(1), 224-238.

Kim, Y. K. and Smith, A. K. (2007). Providing a critical service today for tomorrow's consumers: A relational model of customer evaluations and responses in the childcare industry. Journal of Retailing and Consumer Services 14: 232-245. 
Koryak, O., Mole, K.F., Lockett, A., Hayton, J.C., Ucbasaran, D. \& Hodgkinson, G.P. (2015). Entrepreneurial leadership, capabilities and firm growth. International Small Business Journal, 33(1), 89-105.

Kreiser P, Marino L, Kuratko D \& Weaver K. (2013). Disaggregating entrepreneurial orientation: the non-linear impact of innovativeness, pro-activeness and risk-taking on SME performance. Small Business Economics, 40:273-291.

Kuratko, D. F. \& Hodgetts, R. M. (2004). Entrepreneurship: a contemporary approach. Mason, $\mathrm{OH}$ : South Western.

Li, M. \& Atuahene-Gima, K. (2005). The contingent value of responsive and proactive market orientation on new product program performance. Journal of Product Innovation Management, 22(6), 464-482.

Liu, W. P., Yeung, A. S., \& Farmer, S. (2001). What do parents want from day care services? : perspectives from Australia. Early Childhood Research Quarterly.

Lumpkin, G. T. \& Dess, G. G. (1996). Clarifying the entrepreneurial orientation construct and linking it to performance. Academy of Management Review, 21(1), 135-172.

Majzub, R. M. (2003). Pendidikan Prasekolah Cabaran Kualiti: Universiti Kebangsaan Malaysia, Bangi, Malaysia. Miller, D. (2014). Miller (1983) revisited: a reflection on EO research and some suggestions for the future. Entrepreneurship Theory and Practice, 35(5), 873-894

Milliken, F. J. (1987). Three Types of Perceived Environmental Uncertainty: State, Effect and Response Uncertainty, Academy of Management Review, Vol. 12(1), 133-143.

Molina-Azorín, J. F., López-Gamero, M.D \& Claver Cortés, E. (2011). Environmental uncertainty and environmental management perception: a multiple case study. Journal of Business Research, 64(4), 427-435.

Mwobobia, F. M. (2012). The Challenges Facing Small-Scale Women Entrepreneurs: A Case of Kenya. International Journal of Business Administration. ISSN 1923- 4007(Print) ISSN 1923-4015Nor, M. M. (2006). Realiti trend dan isu dalam pendidikan awal kanak-kanak [Reality trends and issues in early childhood education]. Masalah Pendidikan, 29.

Omar, N., Nazri, M. and Abu, N., (2009). Parents' Perceived Service Quality, Satisfaction and Trust of a Childcare Center: Implication on Loyalty. International Review of Business Research paper Vol.5(5), 299-314.

Onkelinx, J., Manolova, T. S., \& Edelman, L. F. (2015). Human capital and SME internationalization: Empirical evidence from Belgium. International Small Business Journal, 34(6), 818-837.

Rahman, S. A., Amran, A., Ahmad, N.H. \& Taghizadeh, S. K. (2014). Grameen Phone: creating a win-win at the base of the pyramid in Bangladesh. Global Business and Organizational Excellence, 33(5), 41-53.

Ramlall, S. J. (2002). Measuring Human Resource Management's Effectiveness in Improving Performance.

Rauch, A. \& Frese, M. (2007). A contingency approach to small scale business success: a longitudinal study on the effects of environmental hostility and uncertainty on the relationship between planning and success. Babson College Press, Babson Park.

Rauch, A., Wiklund, J., Frese, M. \& Lumpkin, G. (2009). Entrepreneurial Orientation and business Performance: Cumulative Empirical Evidence. Frontiers of Entrepreneurship Research. Wellesley, MA: Babson College.

Razak, R. A. (2011). Entrepreneurial Orientation as a Universal Remedy for the Receding Productivity in Malaysian Small and Medium Enterprises: A Theoretical Perspective. International Journal of Business and Social Science, 2(19). 
Rosenbusch, N., Rauch, A. \& Bausch, A. (2013). The mediating role of entrepreneurial orientation in the task environment-performance relationship: a meta-analysis. Journal of Management, 39(3), 633-659.

Sallen, N. R, Nasir, N. E., Nori, W. M. \& Kassim, C. K. (2017). Small and Medium Enterprises: Critical Problems and Possible Solutions. International Business Management 11(1): 47-52.

Sanya, S. (2013). Limited Access to Credit Limiting SME Growth. Retrieved from www.allafrica.com on 12th June 2013.

Samsami, F., Hosseini, S.H.K., Kordnaeij, A. \& Azar, A. (2015). Managing environmental uncertainty: from conceptual review to strategic management point of view. International Journal of Business and Management, 10(7), 215-229.

Schepers, J., Voordeckers, W., Steijvers, T. \& Laveren, E. (2014). The entrepreneurial orientation-performance relationship in private family firms: the moderating role of socio emotional wealth. Small Business Economics, 43 (1), 39-55.

Simangunsong, E., Hendry, L.C. \& Stevenson, M. (2012). Supply-chain uncertainty: a review and theoretical foundation for future research. International Journal of Production Research, 50 (16), 4493-4523.

SME Corp (2017). SME Annual Report 2016/2016. Retrieved 5 December 2017 from http://www.smecorp.gov.my/index.php/en/sme-annual-report-2015-16.

Spencer, C. and Blades, M. (2006). Children and their environments: Learning, using and designing spaces. Cambridge University Press.

Stam, W. and Elfring, T. (2008). Entrepreneurial orientation and new venture performance: the moderating role of intra- and extra industry social Capital. Academy of Management Journal, 51(1), 97-111.

Statistics of Malaysia Labour Force Survey, Department of Statistics Malaysia (2018). https://www.dosm.gov.my/v1/index.php?r=column/cthemeByCat\&cat=124\&bul_id= MUdWKzdMSjJ0UXh6aG5xTS9oS0h6Zz09\&menu_id=U3VPMldoYUxzVzFaYmN kWXZteGduZz09.

Suliyanto, S., \& Rahab, R. (2012). The role of market orientation and learning orientation in improving innovativeness and performance of small and medium enterprises. Asian Social Science, 8(1), 134.

Swierczek, F. W. \& Thanh, Ha, T. (2003). Entrepreneurial orientation, uncertainty avoidance and firm performance. Entrepreneurship and Innovation, 46-58.

Tang, Z \& Tan, J. (2012). Entrepreneurial orientation and SME performance in China's changing environment: The moderating effects of strategies. Asia Pacific Journal of Management, 29:409-431.

Teece, D., David, S., Pisano, A., Gary, S. A (1997). Dynamic capabilities and strategic management. Strategic Management Journal, 18(7), 509-533.

Tee \& Richardson (2007). A comparison of current PLS path modeling software: Features, ease-of-use, and performance Handbook of partial least square, 737-756, Springer.

U.S. Bureau of Labor Statistics (2017). Bureau of Labor Statistics. Business Employment Dynamics, //www.sba.gov/sites/default/files/advocacy/All_States.pdf.

Van Doorn, S., Jansen, J.J.P., Van den Bosch, F.A.J. \& Volberda, H.W. (2013). Entrepreneurial orientation and firm performance: drawing attention to the senior team. Journal of Product Innovation Management, 30 (5), 821-836

Vij, S. and Bedi, H.S. (2012). Relationship between entrepreneurial orientation and business performance are view of literature. Journal of Business Strategy, 9(3), 17-31.

Wales, W., Wiklund, J. \& McKelvie, A. (2015). What about new entry? Examining the theorized role of new entry in the entrepreneurial-performance relationship? International Small Business Journal, 33 (4), 351-373. 
Wales, W.J. (2016). Entrepreneurial orientation: a review and synthesis of promising research directions. International Small Business Journal, 34(1), 3-15.

Wei, L. \& Ling, Y. (2015). CEO characteristics and corporate entrepreneurship in transition economies: evidence from China. Journal of Business Research, 68(6), 1157-1165.

Wiklund, J. and Shepherd, D. (2011). Entrepreneurial orientation and small business performance: A configurational approach. Journal of Business Venturing, 20(1), 7191. 